\title{
MODEL PROYEKSI PERUBAHAN PENGGUNAAN LAHAN KAWASAN KORIDOR JALAN UTAMA BERBASIS CELLULAR AUTOMATA DAN SIG
}

\section{PROJECTION MODEL OF LAND USE CHANGE IN MAIN ROAD CORRIDOR BASED ON CELLULAR AUTOMATA AND GEOGRAPHIC INFORMATION SYSTEM}

\author{
Sukamto', Imam Buchori² \\ ${ }^{1}$ Kantor Pertanahan Kota Tanjungpinang, Jl. Daeng Kamboja, Simpang Madong, Tanjungpinang; brian.azka@gmail.com \\ ${ }^{2}$ Departemen Perencanaan Wilayah dan Kota, Universitas Diponegoro, Semarang; i.buchori@undip.ac.id
}

Info Artikel:

- Artikel Masuk: 24/07/2018

\begin{abstract}
ABSTRAK
Dampak negatif dari pertumbuhan ekonomi yang pesat adalah adanya alih fungsi lahan yang tidak terkontrol. Model perubahan penggunaan lahan bisa menjadi perangkat dalam rangka memahami dinamika konversi lahan serta variabel yang menjadi faktor pendorongnya. Tujuan penelitian ini adalah menganalisa penerapan model Cellular Automata dalam menganalisa perubahan penggunaan lahan pada wilayah penelitian skala 1:10.000 di sepanjang koridor jalan Solo-Yogyakarta di Kabupaten Klaten khususnya perubahan lahan sawah menjadi lahan terbangun. Pemodelan simulasi perubahan penggunaan lahan dalam penelitian ini dilakukan dengan menggunakan pendekatan cellular automata pada skala detail 1:10.000 dengan memperhatikan trend perubahan penggunaan lahan di sepanjang koridor jalan Solo-Yogyakarta di Kabupaten Klaten pada kurun waktu tahun $2007-2017$. Hasil analisis pola perubahan penggunaan lahan dari tahun 2007 sampai dengan 2017 pertumbuhan dengan perkembangan terbesar adalah penggunaan perumahan yang mengalami kenaikan luas sebesar 217,41 $\mathrm{Ha}$, sedangkan jenis penggunaan tanah yang mengalami konversi lahan menjadi penggunaan lain adalah sawah yang mengalami penurunan luas sebesar $365,76 \mathrm{Ha}$. Hasil analisis peta proyeksi penggunaan lahan tahun 2031 menunjukkan kecenderungan arah perkembangan lahan terbangun masih berkutat di daerah yang dekat dengan pusat Kota Klaten. Komparasi Peta proyeksi Tahun 2031 telah sesuai dan terakomodir dalam Peta Rencana Pola Ruang RTRW Kabupaten Klaten dengan tingkat kesesuaian pemanfaatan ruang yaitu 94,42\%.

Kata Kunci : Perubahan Penggunaan Lahan, Pemodelan, Cellular Automata
\end{abstract}

\section{ABSTRACT}

The negative impact of a rapid economic growth is the uncontrolled land conversion. The modeling of land use change can be used as a tool to understand the dynamics of land conversion and the variables of driving factors. The purpose of this research is to investigate how cellular automata model analyzes the land use change in a research area of 1: 10.000 scale along SoloYogyakarta road corridor in Klaten Regency, especially the change of paddy field into developed land. In this research, the simulation model of land use change was created by using cellular automata on a 1: 10,000 scale by considering the trend of land use changes along Solo-Yogyakarta road corridor in Klaten regency from 2007 to 2017. The results show that there were the biggest development was the use of housing which experienced an increase of $217.41 \mathrm{Ha}$, whereas land use type which converted land into another usage is paddy field, decreased by $365.76 \mathrm{Ha}$. The results of the analysis of land use prediction in 2031 showed that the tendency of land development direction is still concentrated in the area close to Klaten city center. The comparison evaluation results between RTRW Map of Klaten Regency Year 2011-2031 and Land Use Prediction in 2031 with cellular automata modeling shows hight level of landuse conforming at $94.42 \%$.

Keyword: Land use change, Modelling, Cellular Automata

Copyright $\odot 2018$ JPWK-UNDIP This open access article is distributed under a Creative Commons Attribution (CC-BY-NC-SA) 4.0 International license.

Cara men-sitasi:

Sukamto \& Buchori, Imam. (2018). Model Proyeksi Perubahan Penggunaan Lahan Kawasan Koridor Jalan Utama Berbasis Cellular Automata dan SIG. Jurnal Pembangunan Wilayah dan Kota, 14 (4), 307-322 


\section{PENDAHULUAN}

Penggunaan lahan adalah hasil dari kegiatan manusia baik yang berlangsung secara siklus atau permanen pada sumberdaya lahan alami maupun buatan untuk pemenuhan kebutuhan hidup manusia (Setiady dan Danoedoro, 2014). Dalam pemenuhan kebutuhannya, manusia membutuhkan ruang berupa tanah untuk melakukan berbagai aktivitas kehidupan. Penggunaan lahan pada suatu wilayah dipengaruhi juga oleh keberadaan sarana dan prasaran, khususnya prasarana dan sarana transportasi (Rahayu et al, 2015). Persaingan terhadap pemanfaatan lahan tersebut muncul akibat adanya tiga fenomena ekonomi dan sosial yaitu keterbatasan sumber daya lahan, pertambahan penduduk dan pertumbuhan ekonomi (Irawan, 2008). Tingginya aktivitas ekonomi yang terjadi mengakibatkan permintaan terhadap lahan sebagai penunjang kegiatan ekonomi juga mengalami peningkatan. Perubahan penggunaan lahan sangat dipengaruhi oleh aktivitas manusia yang dilakukan karena sifat lahan yang tetap sedangkan aktivitas manusia berubah-ubah dan cenderung meningkat dalam pemenuhan kebutuhan hidupnya. Alih fungsi lahan atau perubahan penggunaan lahan diakibatkan oleh semakin meningkatnya permintaan yang tinggi karena aktivitas manusia. Alih fungsi lahan terjadi khususnya pada lahan pertanian yang beralih fungsi menjadi non pertanian. Lahan sawah memegang peranan penting dalam penyediaan kebutuhan beras. Produksi beras di Indonesia 94\% dihasilkan dari usaha tani padi sawah, sisanya dihasilkan dari usaha tani padi lahan kering. Pulau Jawa masih menjadi penyumbang produksi beras terbesar yaitu mencapai 53\% dari total produksi beras nasional (Ambarwulan et al, 2014).

Kabupaten Klaten adalah salah satu Kabupaten di Provinsi Jawa Tengah yang secara geografis terletak pada koridor penghubung dua kota besar antar provinsi, yaitu Kota Surakarta dan Kota Yogyakarta. Perkembangan di Kota Surakarta dan Kota Yogyakarta secara langsung maupun tidak langsung memberikan pengaruh dalam perkembangan yang terjadi di Kota Klaten terutama di sepanjang koridor Jalan Solo-Yogyakarta. Perubahan penggunaan lahan dapat dianalisis dengan membangun suatu model. Model merupakan salah satu pendekatan untuk mempelajari sesuatu yang terjadi di alam ini dan dapat memprediksi keadaan yang akan datang (Munibah, 2008). Pemodelan Cellular Automata adalah model yang sangat popular digunakan untuk melakukan simulasi pola perubahan penggunaan lahan dan sudah digunakan dalam banyak penelitian. Penutup lahan dan penggunaan lahan sejatinya mempunyai pengertian yang berbeda. Penutup lahan adalah kondisi biofisik permukaan bumi dan di dekat permukaan bumi, sedangkan penggunaan lahan berkaitan dengan kondisi dan karakteristik biofisik lahan serta upaya untuk memanipulasinya (Susilo, 2008). Penggunaan lahan berhubungan dengan fungsi atau manfaat dari lahan yang diberdayakan oleh manusia dan dapat didefinisikan sebagai bermacam aktivitas manusia yang berhubungan langsung dengan lahan, menggunakan dan menerima dampak dari aktivitas tersebut. Liilesand dan Kiefer (1979) membuat definisi penggunaan lahan sebagai hubungan kegiatan manusia pada suatu bidang lahan. Penggunaan lahan dapat dikelompokkan dalam 2 (dua) golongan besar yaitu penggunaan lahan pertanian dan penggunaan lahan non pertanian.

Perubahan penggunaan lahan terjadi ketika manusia sebagai pengguna lahan memutuskan untuk mengganti sumber daya ke arah tujuan lain yang berbeda, dengan dampak yang diinginkan maupun yang tidak dinginkan. Penyebab dari perubahan penggunaan adalah kelangkaan sumberdaya; perubahan kesempatan akibat pasar; intervensi kebijakan dari luar; hilangnya kapasitas adaptasi dan meningkatnya kerentanan; perubahan dalam organisasi sosial dalam mengakses sumberdaya dan dalam tingkah laku (Lambin et al, 2003). Analisis perubahan penggunaan lahan pada dasarnya adalah analisis hubungan antara manusia dan lahan untuk menjawab pertanyaan-pertanyaan mengapa, kapan, bagaimana, dan dimana perubahan penggunaan lahan bisa terjadi. Tujuan dari analisis perubahan penggunaan lahan adalah dalam bentuk: deskripsi atau penjelasan, explanation (eksplanasi), prediksi, impact assessment (kajian dampak), prescription dan evaluasi (Helen Briassoulis, 2005). Ma, et al (2012) dalam penelitiannya, menyebutkan perubahan dinamis pada areal lahan basah di pesisir Tianjin China cenderung dipengaruhi oleh perubahan iklim dari pemanasan global dan aktifitas manusia yang terus menerus menekan fungsi lahan basah pesisir bagi pemenuhan kebutuhan. 
Adanya ketidakseimbangan antara penawaran dan permintaan dimana penawaran terbatas sedangkan permintaan tak terbatas menyebabkan terjadinya alih fungsi lahan. Menurut Barlowe (1978), faktor faktor yang mempengaruhi penawaran lahan adalah karateristik fisik alamiah, faktor ekonomi, faktor teknologi, dan faktor kelembagaan. Selain itu, faktor-faktor yang mempengaruhi permintaan lahan adalah populasi penduduk, perkembangan teknologi, kebiasaan dan tradisi, pendidikan dan kebudayaan, pendapatan dan pengeluaran, selera dan tujuan, serta perubahan sikap dan nilai-nilai yang disebabkan oleh perkembangan usia. Lambin et al (2003) menyebutkan ada enam faktor yang menjadi pemicu terjadinya perubahan penggunaan lahan. Faktor tersebut adalah perubahan kondisi alamiah, faktor ekonomi dan teknologi, faktor demografi, faktor institusi, faktor budaya dan faktor globalisasi. Perubahan penggunaan lahan bisa dipicu salah satu dari faktor yang sudah disebutkan itu maupun gabungan dari beberapa faktor yang kemudian saling berkaitan. Membangun model perubahan penggunaan lahan dilakukan secara analisis spasial dengan bantuan penginderaan jauh. Lillesand dan Kiefer (1979) menyatakan bahwa penginderaan jauh adalah ilmu atau seni untuk memperoleh informasi mengenai objek, daerah atau gejala, dengan jalan menganalisis data yang diperoleh dengan menggunakan alat, tanpa melakukan kontak langsung dengan objek, daerah atau gejala yang akan dikaji. Dari definisi yang telah diuraikan tersebut dapat diambil kesimpulan bahwa penginderaan jauh merupakan ilmu dan seni untuk mengindera atau menganalisis permukaan bumi dari jarak yang jauh, dimana perekaman dilakukan di udara atau di angkasa dengan menggunakan alat (sensor) dan wahana. Data penginderaan jauh dapat berupa data digital atau data numerik maupun data visual. Data citra berupa gambaran yang mirip wujud aslinya atau paling tidak berupa gambaran planimetrik.sedangkan data non citra pada umumnya berupa garis atau grafik (Sutanto, 1986).

Menurut Sugandi, Somantri, \& Sugito, (2009) komponen utama Sistem Informasi Geografis dapat dibagi kedalam 4 komponen utama, yaitu : (1) Hardware, (2) Software, (3) Manajemen atau organisasi dan (4) User atau pemakai. Kombinasi yang tepat diantara komponen tersebut akan menentukan keberhasilan suatu proyek pengembangan Sistem Informasi Geografis. Data yang diolah dalam GIS pada dasarnya terdiri dari data spasial dan data atribut yang sudah dalam bentuk digital. Analisis yang digunakan dalam GIS adalah analisis spasial dan analisis atribut. Pemodelan spasial penggunaan lahan dapat digunakan untuk melakukan analisis spasial perubahan penggunaan lahan dalam time series yang telah ditentukan. Tujuan dari pemodelan yang lain adalah perencana dapat menentukan kesesuaian dan efisiensi suatu rencana, selain itu memungkinkan perencana dalam pengambilan keputusan terhadap kebijakan di suatu wilayah dan kota. Berikut pada Gambar 1. merupakan alur dalam proses pemodelan.

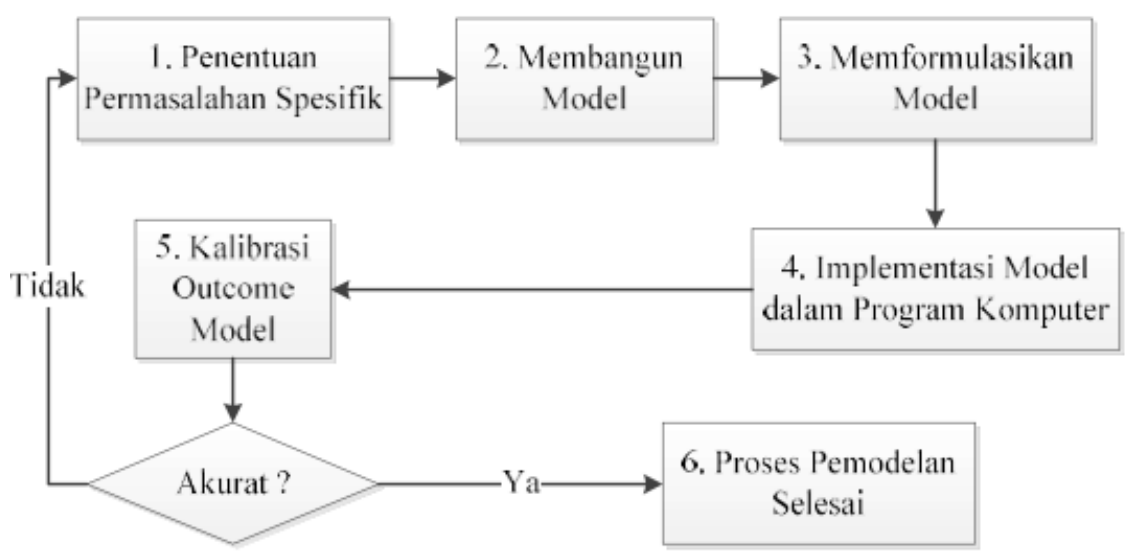

Gambar 1. Alur Proses Pemodelan (Caldwell dan Ram (1999) dalam Sadewo,2018)

Model dapat dibagi menjadi 3 yaitu:

1. Model Empiris dan Statistik, misalnya Model Markov Chain dan Regresi,

2. Model Dinamis misalnya Model Cellular Automata (CA) dan

3. Model Terintegrasi misalnya CLUE (conversion of land use and its Effects) (Guan et al., 2011). 
Cellular Automata (CA) adalah model yang awalnya dipahami oleh Ulam dan Von Neumann pada tahun 1940 untuk membuat kerangka kerja formal untuk menyelidiki suatu perilaku kompleks. Susunan sel tersebut juga dapat membentuk grid segi empat sederhana maupun susunan lain, seperti sarang lebah yang terdiri dari bagian-bagian berbentuk segi enam (Sulistyanto \& Pulungan, 2014). Keadaan suatu cellular automata sepenuhnya dipengaruhi oleh variabel yang dimiliki tiap sel. Deep \& Saklani (2014) menarik suatu kesimpulan dari penelitiannya bahwa Cellular Automata (CA) dapat menggabungkan komponen spasial dengan aturan aturan sederhana, mudah, dinamis serta meningkatkan efisiensi dalam pengolahan komputasi. Model yang dibangun pada Cellular Automata termasuk memasukkan unsur sosial-ekonomi, kedekatan dengan penggunaan lahan yang ada dan faktor-faktor geografis dalam membatasi perubahan penggunaan lahan sebagai faktor pembatas. Cellular Automa merupakan konsep yang dapat menggambarkan adanya transisi/pergerakan dari setiap elemen atau objek yang dinamakan automaton. Secara sederhana, automaton (bentuk tunggal automata) adalah suatu mekanisme pemrosesan diskrit. Mekanisme yang dimaksud adalah kemampuan untuk berubah berdasarkan sekumpulan aturan-aturan yang diterapkan pada dirinya sendiri (objek) dan juga berbagai masukan dari luar (Septiono \& Mussadun, 2016)

Klasifikasi pengunaan lahan yang digunakan dalam penelitian ini berpedoman pada Buku Norma, Standar, Prosedur dan Kriteria (NSPK) Survei dan Pemetaan Tematik Pertanahan 2012 yang di terbitkan oleh Direktorat Pemetaan Tematik Pertanahan Badan Pertanahan Nasional Tahun 2012 dan faktor pendorong perubahan penggunaan lahan secara umum yaitu kepadatan penduduk, jarak ke pusat perdagangan, jarak ke perumahan eksisting, jarak ke industri eksisting, jarak ke sungai, jarak ke jalan arteri, jarak ke jalan kolektor, jarak ke jalan lokal, jarak ke kota Kecamatan, Jarak ke Pusat Kota (Klaten, Solo, Yogyakarta) dan Kelerengan. Faktor-faktor pendorong perubahan penggunaan lahan dapat dilihat dalam Tabel 1.

Tabel 1. Faktor Pendorong Perubahan Penggunaan Lahan (Hasil Analisis,2018)

\begin{tabular}{|c|l|}
\hline No & Faktor Pendorong Perubahan Penggunaan Lahan \\
\hline 1 & Kepadatan Penduduk \\
\hline 2 & Jarak Ke Pusat Perdagangan \\
\hline 3 & Jarak Ke Perumahan Eksisting \\
\hline 4 & Jarak Ke Industri Eksisting \\
\hline 5 & Jarak Ke Sungai \\
\hline 6 & Kelerengan \\
\hline 7 & Jarak Ke Kota Kecamatan \\
\hline 8 & Jarak Ke Pusat Kota (Klaten, Solo, Yogyakarta) \\
\hline 9 & Jarak Ke Jalan Arteri \\
\hline 10 & Jarak Ke Jalan Kolektor \\
\hline 11 & Jarak Ke Jalan Lokal \\
\hline
\end{tabular}

Penelitian terkait dengan perubahan lahan adalah konversi lahan pertanian pada koridor Jalan SoloYogyakarta di Kabupaten Klaten adalah penelitian yang dilakukan oleh Sri Rahayu dan tim pada tahun 2015. Rahayu, et all (2015) melakukan penelitian dengan mengkaji konversi lahan pertanian di koridor Jalan Solo-Yogyakarta dalam kurun waktu 1994-2013 tanpa melakukan pemodelan proyeksi dalam tempo waktu di masa mendatang. Rahayu, et all (2015) melakukan analisa spasial dengan cara interpretasi Citra Landsat dan ALOS, meng-overlay peta penggunaan lahan yang dihasilkan, serta pembandingan peta 
penggunaan lahan dengan Peta Rencana Tata Ruang Wilayah (RTRW) Kabupaten Klaten. Penelitian yang lain adalah penelitian yang dilakukan Setiady dan Danoedoro tahun 2014 mengenai perubahan lahan pertanian sawah sebagian Kabupaten Klaten dan sekitarnya menggunakan cellular automata dengan analisa regresi logistic biner dan Cellular Automata-Markov Chain untuk mengetahui perbedaan nilai uji akurasi hasil pemodelan.

Tujuan penelitian ini adalah penerapan pemodelan alghoritma Cellular Automata dalam menganalisa perubahan penggunaan lahan pada wilayah penelitian skala detail 1:10.000 di sepanjang koridor Jalan SoloYogyakarta di Kabupaten Klaten khususnya perubahan lahan sawah menjadi lahan terbangun. Pemodelan yang dibangun mempunyai tujuan untuk mengetahui trend perubahan lahan yang terjadi berdasarkan faktor - faktor yang menjadi pendorong perubahan lahan yang sudah ditentukan sebelumnya dan membuat simulasi prediksi penggunaan lahan pada masa yang akan datang. Hasil dari pemodelan berupa peta prediksi penggunaan lahan tahun 2031 yang digunakan dalam melakukan analisis perbandingan penggunaan lahan untuk mengetahui kesesuaian pemanfaatan ruang dalam rencana pola ruang wilayah RTRW Kabupaten Klaten tahun 2011-2031.

\section{DATA DAN METODE}

\subsection{DATA PENELITIAN}

Pendekatan yang digunakan dalam penelitian ini adalah pendekatan kuantitatif berbasis spasial dengan data spasial berupa data raster dan unit cell yang digunakan sebagai input dalam membangun model proyeksi penggunaan lahan tahun 2031. Obyek penelitian adalah perubahan penggunaan lahan di koridor jalan Solo-Yogyakarta di Kabupaten Klaten pada kurun waktu tahun 2007-2012 dan tahun 2012-2017. Simulasi perubahan penggunaan lahan di masa depan diolah dengan menggunakan algorithma Cellular Automata. Alat dan bahan yang digunakan dalam penelitian ini meliputi:

1. Alat
a. Komputer/laptop
b. GPS (Global Positioning System)
c. Software ArcGIS 10.3
d. Software Expert Choice 11
e. Landuse $\operatorname{Sim} 2.3 .1$
f. Idrisi Selva

2. Bahan
a. Citra tahun 2007, 20012 (Digital Globe) dan 2017 (CNES/Airbus)
b. Peta Kemiringan Lereng
c. Peta Jaringan Jalan dan Jaringan Sungai
d. Data Kependudukan
e. Peta Pola Ruang RTRW Kabupaten Klaten

\subsection{GAMBARAN UMUM WILAYAH STUDI}

Penelitian ini difokuskan pada wilayah sepanjang koridor jalan Solo-Yogyakarta dengan luas batasan wilayah adalah $14.673,50$ Ha. Daerah penelitian difokuskan pada daerah sepanjang koridor Jalan SoloYogyakarta yang berada di Kabupaten Klaten yang terkena pengaruh dari jalur utama tersebut. Daerah penelitian terdiri 16 kecamatan yang tersebar sepanjang koridor jalan. Kecamatan yang menjadi lokasi penelitian adalah Kecamatan Ceper, Delanggu, Gantiwarno, Jogonalan, Juwiring, Kalikotes, Karanganom, Kebonarum, Klaten Selatan, Klaten Tengah, Klaten Utara, Ngawen, Polanharjo, Prambanan, Trucuk dan Wonosari. Kondisi topografi di wilayah penelitian adalah dataran landau dengan ketinggian wilayah 100 mdpal sampai dengan 400 mdpal. Kemeringan lereng di daerah penelitian didominasi oleh satuan morfologi daerah yang relative datar dengan rentang kelas kemiringan lereng $0-2 \%$ dan $>2 \%-2 \%$. Didaerah penelitian tidak ada morfologi kemiringan lereng diatas $40 \%$ atau morfologi kepadatan terjal. Peta lokasi penelitian ini tergambar dalam Gambar 2. 


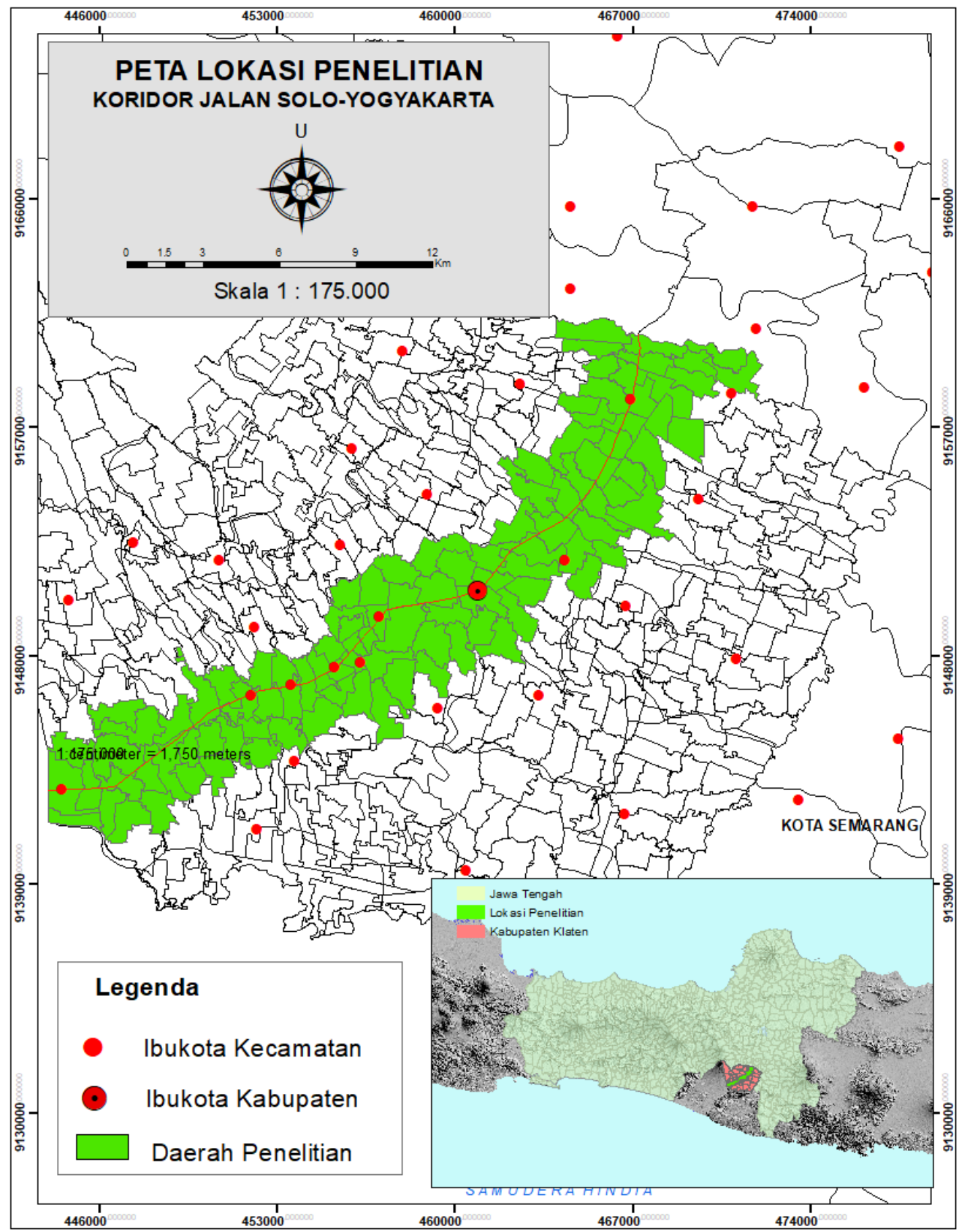

Gambar 2. Peta lokasi penelitian (HAsil Analisis, 2018)

\section{HASIL DAN PEMBAHASAN}

1. Interpretasi dan Identifikasi Distribusi Penggunaan Lahan Tahun 2007,2012 dan 2017

Interpretasi penggunaan lahan berdasarkan ketiga citra tahun pengamatan tersebut dilakukan dengan metode On Screen Digitazing dengan menggunakan klasifikasi penggunaan lahan sesuai dengan NSPK Tematik BPN RI Tahun 2012. Software yang digunakan dalam proses digitasi adalah ArcGIS 10.3 dan interpretasi penggunaan lahan menggunakan skala 1:10.000 dengan proyeksi geografis WGS 1986 dan UTM $49 \mathrm{~S}$ sesuai dengan lokasi penelitian. Hasil interpretasi diperoleh 29 jenis penggunaan lahan yaitu aneka industri, danau.situ/telaga, hutan kota, jalan arteri, jalan kereta api, jalan kolektor, jalan lokal, jasa pemerintah, jasa kesehatan, jasa lainnya, jasa pariwisata, jasa pendidikan, jasa perdagangan, jasa perhubungan, jasa peribadatan, kebun campuran, kolam air tawar, kuburan/pemakaman, lapangan 
olahraga, padang rumput, pergudangan, pertambanagan terbuka, perumahan, sawah, semak, sungai, taman umum, tanah terbuka sementara dan tegalan/ladang. Berdasakan hasil interpretasi secara visual dan digital, kelas penggunaan lahan pada masing-masing tahun perekaman tahun 2007, 2012 dan 2017 dibagi menjadi 29 kelas penggunaan tanah seperti tersaji dalam Gambar 3.

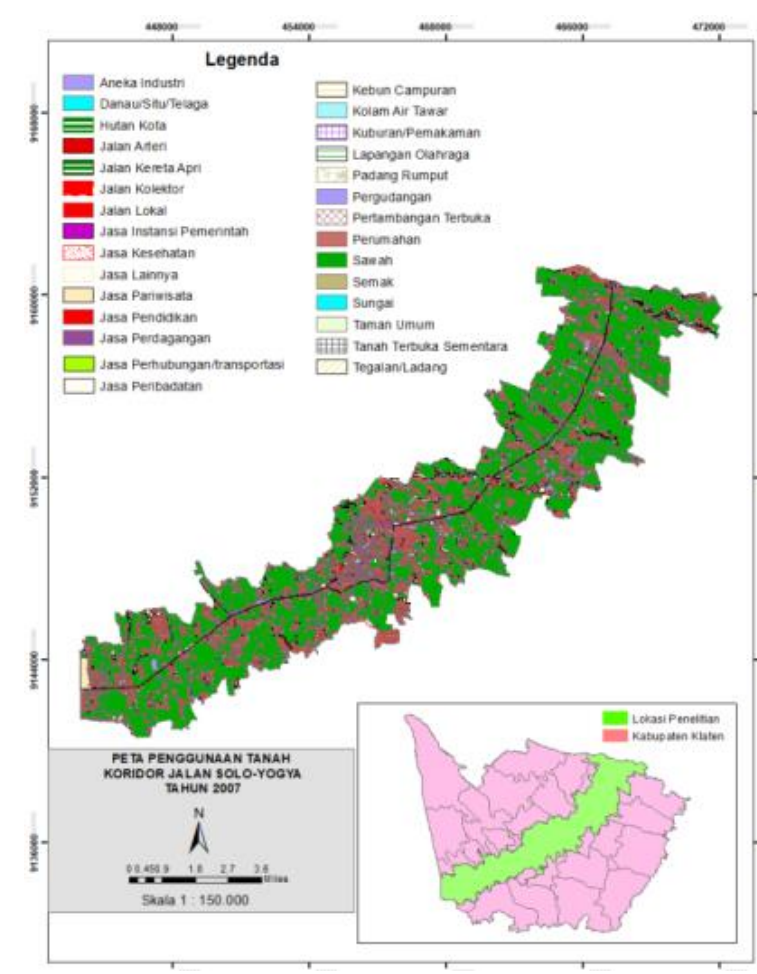

(a)

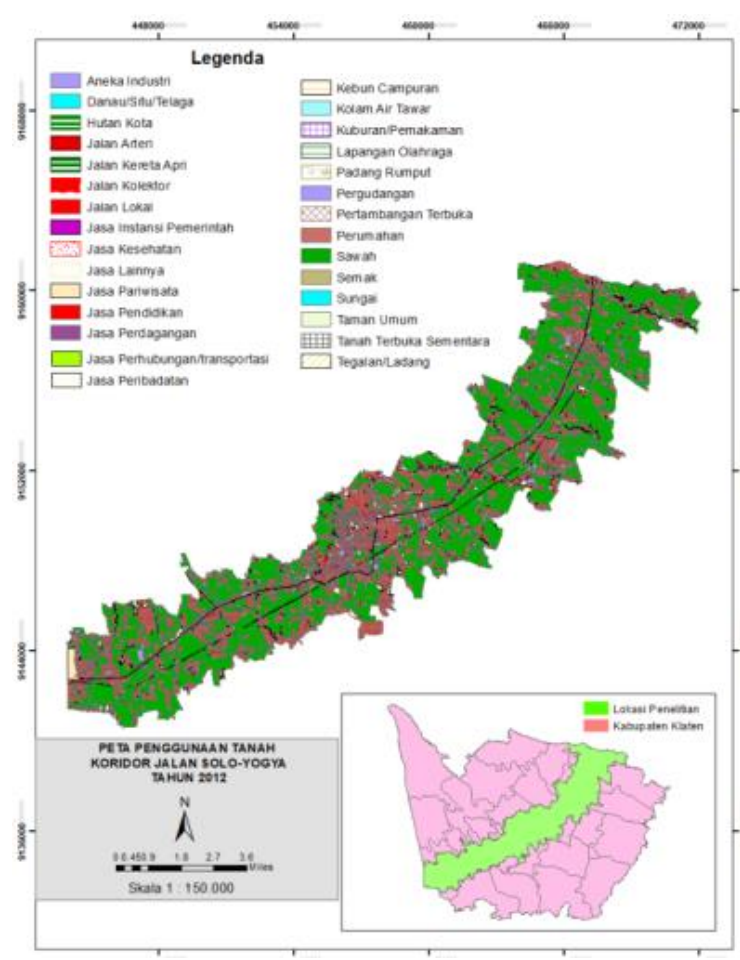

(b)

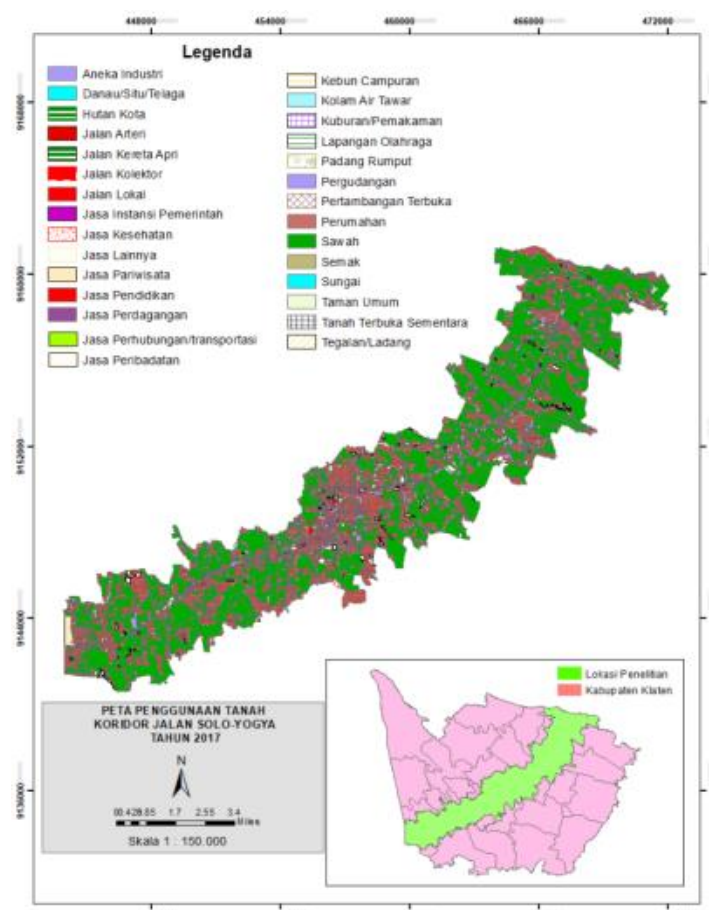

(c)

Gambar 3. Peta Pola Penggunaan Lahan (a) Tahun 2007 (b) Tahun 2012

(c) Tahun 2017 (hasil analisis,2018) 
Hasil analisa distribusi dan perubahan penggunaan lahan selama kurun waktu tahun 2007 - 2017 sebagaimana disajikan dalam Tabel 2.

Tabel 2. Distribusi Dan Perubahan Penggunaan Lahan (Hasil Analisis,2018)

\begin{tabular}{|c|c|c|c|c|c|c|c|}
\hline \multirow[b]{2}{*}{ KODE } & \multirow[b]{2}{*}{ PENGGUNAAN TANAH } & \multicolumn{6}{|c|}{ LUAS (Ha) } \\
\hline & & $\begin{array}{c}\text { Tahun } \\
2007\end{array}$ & $\%$ Luas & Tahun 2012 & $\%$ Luas & Tahun 2017 & $\%$ Luas \\
\hline LU_1 & Aneka Industri & 87,59 & 0,60 & 101,80 & 0,69 & 127,84 & 0,87 \\
\hline LU_2 & Danau/Situ/Telaga & 0,28 & 0,00 & 0,28 & 0,00 & 0,28 & 0,00 \\
\hline LU_3 & Hutan Kota & 0,68 & 0,01 & 0,68 & 0,01 & 0,68 & 0,01 \\
\hline LU_4 & Jalan Arteri & 57,37 & 0,39 & 57,37 & 0,39 & 57,37 & 0,39 \\
\hline LU_5 & Jalan Kereta Api & 53,14 & 0,36 & 53,14 & 0,36 & 53,14 & 0,36 \\
\hline LU_6 & Jalan Kolektor & 4,40 & 0,03 & 4,40 & 0,03 & 4,40 & 0,03 \\
\hline LU_7 & Jalan Lokal & 112,01 & 0,76 & 112,01 & 0,76 & 112,01 & 0,76 \\
\hline LU_8 & Jasa Pemerintah & 37,04 & 0,25 & 37,34 & 0,25 & 37,95 & 0,26 \\
\hline LU_9 & Jasa Kesehatan & 33,57 & 0,23 & 37,91 & 0,26 & 37,91 & 0,26 \\
\hline LU_10 & Jasa Lainnya & 0,11 & 0,00 & 0,11 & 0,00 & 0,11 & 0,00 \\
\hline LU_11 & Jasa Pariwisata & 53,00 & 0,36 & 53,00 & 0,36 & 53,00 & 0,36 \\
\hline LU_12 & Jasa Pendidikan & 130,84 & 0,89 & 132,90 & 0,91 & 136,64 & 0,93 \\
\hline LU_13 & Jasa Perdagangan & 353,61 & 2410,00 & 377,02 & 2569,00 & 389,65 & 2655,00 \\
\hline LU_14 & Jasa Perhubungan & 4,97 & 0,03 & 4,97 & 0,03 & 8,70 & 0,06 \\
\hline LU_15 & Jasa Peribadatan & 6,62 & 0,05 & 6,62 & 0,05 & 6,62 & 0,05 \\
\hline LU_16 & Kebun Campuran & 234,74 & 1600,00 & 237,11 & 1616,00 & 246,00 & 1676,00 \\
\hline LU_17 & Kolam Air Tawar & 5,59 & 0,04 & 5,59 & 0,04 & 5,59 & 0,04 \\
\hline LU_18 & Kuburan/Pemakaman & 57,08 & 0,39 & 57,08 & 0,39 & 57,08 & 0,39 \\
\hline LU_19 & Lapangan Olahraga & 36,47 & 0,25 & 36,47 & 0,25 & 36,47 & 0,25 \\
\hline LU_20 & Padang Rumput & 2,17 & 0,02 & 2,17 & 0,02 & 2,17 & 0,02 \\
\hline LU_21 & Pergudangan & 8,62 & 0,06 & 10,16 & 0,07 & 19,98 & 0,14 \\
\hline LU_22 & Pertambangan Terbuka & 4,49 & 0,03 & 8,71 & 0,06 & 8,71 & 0,06 \\
\hline LU_23 & Perumahan & 4476,11 & 30505,00 & 4620,86 & 31491,00 & 4693,52 & 31986,00 \\
\hline LU_24 & Sawah & 8609,64 & 58675,00 & 8400,54 & 57250,00 & 8243,88 & 56182,00 \\
\hline LU_25 & Semak & 0,41 & 0,00 & 0,41 & 0,00 & 0,41 & 0,00 \\
\hline LU_26 & Sungai & 159,93 & 1090,00 & 159,93 & 1090,00 & 159,93 & 1090,00 \\
\hline LU_27 & Taman Umum & 2,25 & 0,02 & 5,98 & 0,04 & 5,98 & 0,04 \\
\hline LU_28 & Tanah Terbuka Sementara & 27,80 & 0,19 & 33,21 & 0,23 & 45,28 & 0,31 \\
\hline LU_29 & Tegalan/Ladang & 113,00 & 0,77 & 115,76 & 0,79 & 122,23 & 0,83 \\
\hline & Total & 14673,53 & 100,00 & 14673,53 & 100,00 & 14673,53 & 100,00 \\
\hline
\end{tabular}

Dari hasil analisis perubahan penggunaan lahan dari tahun 2007 sampai dengan 2012 dapat dilihat adanya penambahan dan pengurangan luas pada kelas penggunaan tanah. Penggunaan tanah yang terbesar dan signifikan di sepanjang koridor jalan Solo-Yogyakarta adalah sawah. Pada tahun 2007 luas sawah adalah 8.609,64 ha atau 58,67 dari total luas keseluruhan daerah penelitian, tetapi pada tahun 2012 terjadi penurunan luas sawah sebesar $1,43 \%$ atau seluas 209,10 ha. Penggunaan tanah terbesar kedua adalah perumahan. Luas penggunaan tanah perumahan pada tahun 2007 adalah 4.476,11 ha atau sebesar 
30,50\%. Pada tahun 2012 luas perumahan ini mengalami kenaikan seluas 144,69 ha menjadi 4620,80 ha (31,49\%)

2. Pola Perubahan Penggunaan Lahan Tahun 2007-2012 dan Tahun 2012-2017

Identifikasi laju perubahan penggunaan lahan digunakan dalam melakukan simulasi proyeksi pola perubahan penggunaan lahan di masa yang akan datang. Pola perubahan penggunaan lahan dapat dilihat dari laju perubahan suatu penggunaan lahan satu menjadi penggunaan lahan yang lainnya. Pola perubahan penggunaan lahan dilakukan dengan melakukan overlay dengan metode intersect pada perangkat lunak ArcGIS 10.3 sehingga dapat diketahui pola penggunaan lahan beserta luasnya. Analisis laju perubahan penggunaan lahan tahun 2007 - 2012 dan tahun 2012-2017 tersaji dalam Tabel 3. dan Tabel 4.

Tabel 3. Pola Pertumbuhan Lahan Tahun 2007 dan 2012 (Hasil Analisis,2018)

\begin{tabular}{|c|c|c|c|c|c|}
\hline \multirow{2}{*}{ KODE } & \multirow{2}{*}{ PENGGUNAAN TANAH } & \multicolumn{2}{|c|}{ LUAS (Ha) } & \multirow{2}{*}{$\begin{array}{c}\sum \text { Perubahan } \\
(\mathrm{Ha})\end{array}$} & \multirow{2}{*}{ Persentase } \\
\hline & & Tahun 2007 & Tahun 2012 & & \\
\hline LU_1 & Aneka Industri & 87,59 & 101,80 & 14,21 & 16,22 \\
\hline LU_8 & Jasa Pemerintah & 37,04 & 37,34 & 0,30 & 0,81 \\
\hline LU_9 & Jasa Kesehatan & 33,57 & 37,91 & 4,34 & 12,93 \\
\hline LU_12 & Jasa Pendidikan & 130,84 & 132,90 & 2,06 & 1,57 \\
\hline LU_13 & Jasa Perdagangan & 353,61 & 377,02 & 23,41 & 6,62 \\
\hline LU_16 & Kebun Campuran & 234,74 & 237,11 & 2,37 & 1,01 \\
\hline LU_21 & Pergudangan & 8,62 & 10,16 & 1,54 & 17,87 \\
\hline LU_22 & Pertambangan Terbuka & 4,49 & 8,71 & 4,22 & 93,99 \\
\hline LU_23 & Perumahan & 4476,11 & 4620,86 & 144,75 & 3,23 \\
\hline LU_24 & Sawah & 8609,64 & 8400,54 & $-209,10$ & $-2,43$ \\
\hline LU_27 & Taman Umum & 2,25 & 5,98 & 3,73 & 165,78 \\
\hline LU_28 & Tanah Terbuka Sementara & 27,80 & 33,21 & 5,41 & 19,46 \\
\hline LU_29 & Tegalan/Ladang & 113,00 & 115,76 & 2,76 & 2,44 \\
\hline
\end{tabular}

Tabel 3. Pola Pertumbuhan Lahan Tahun 2012 dan 2017 (Hasil Analisis,2018)

\begin{tabular}{|c|c|c|c|c|c|}
\hline \multirow{2}{*}{ KODE } & \multirow{2}{*}{ PENGGUNAAN TANAH } & \multicolumn{2}{|c|}{ LUAS (Ha) } & \multirow{2}{*}{$\begin{array}{c}\sum \text { Perubahan } \\
(\mathrm{Ha})\end{array}$} & \multirow{2}{*}{ Persentase } \\
\hline & & Tahun 2012 & Tahun 2017 & & \\
\hline LU_1 & Aneka Industri & 101,80 & 127,84 & 26,04 & 25,58 \\
\hline LU_8 & Jasa Pemerintah & 37,34 & 37,95 & 0,61 & 1,63 \\
\hline LU_12 & Jasa Pendidikan & 132,90 & 136,64 & 3,74 & 2,81 \\
\hline LU_13 & Jasa Perdagangan & 377,02 & 389,65 & 12,63 & 3,35 \\
\hline LU_14 & Jasa Perhubungan & 4,97 & 8,70 & 3,73 & 75,05 \\
\hline LU_16 & Kebun Campuran & 237,11 & 246,00 & 8,89 & 3,75 \\
\hline LU_21 & Pergudangan & 10,16 & 19,98 & 9,82 & 96,65 \\
\hline LU_23 & Perumahan & 4620,86 & 4693,52 & 72,66 & 1,57 \\
\hline LU_24 & Sawah & 8400,54 & 8243,88 & $-156,66$ & $-1,86$ \\
\hline LU_28 & Tanah Terbuka Sementara & 33,21 & 45,28 & 12,07 & 36,34 \\
\hline LU_29 & Tegalan/Ladang & 115,76 & 122,23 & 6,47 & 5,59 \\
\hline
\end{tabular}

3. Analisis Peta Potensi Transisi Perubahan Lahan

Analisa peta aturan transisi berupa peta yang menunjukkan kecenderungan perubahan penggunaan lahan di dalam lokasi penelitian yang sudah ditentukan aturannya terlebih dahulu. Aturan yang dimaksud didasarkan pada faktor pendorong perubahan lahan, bobot masing-masing faktor pendorong dan atau 
bisa disertai dengan faktor penghambat perubahan penggunaan lahan apabila ada skenario yang akan dibangun.

Tabel 5. Aturan Transisi Peta Kesesuaian Lahan (Hasil Analisis,2018)

\begin{tabular}{|c|c|c|c|c|c|c|c|c|}
\hline \multirow{2}{*}{ KODE } & \multirow{2}{*}{ PENGGUNAAN TANAH } & \multicolumn{7}{|c|}{ PETA KESESUAIAN LAHAN } \\
\hline & & LU_1 & LU_13 & LU_16 & LU_21 & LU_23 & LU_28 & LU_29 \\
\hline LU_1 & Aneka Industri & $\mathrm{V}$ & $x$ & $x$ & $x$ & $x$ & $x$ & $x$ \\
\hline LU_2 & Danau/Situ/Telaga & $x$ & $x$ & $x$ & $x$ & $x$ & $x$ & $x$ \\
\hline LU_3 & Hutan Kota & $x$ & $x$ & $x$ & $x$ & $x$ & $x$ & $x$ \\
\hline LU_4 & Jalan Arteri & $x$ & $x$ & $x$ & $x$ & $x$ & $x$ & $x$ \\
\hline LU_5 & Jalan Kereta Api & $x$ & $x$ & $x$ & $x$ & $x$ & $x$ & $x$ \\
\hline LU_6 & Jalan Kolektor & $x$ & $x$ & $x$ & $x$ & $x$ & $x$ & $x$ \\
\hline LU_7 & Jalan Lokal & $\mathrm{X}$ & $x$ & $x$ & $x$ & $x$ & $\mathrm{X}$ & $x$ \\
\hline LU_8 & Jasa Pemerintah & $x$ & $x$ & $x$ & $x$ & $x$ & $x$ & $x$ \\
\hline LU_9 & Jasa Kesehatan & $x$ & $x$ & $x$ & $x$ & $x$ & $\mathrm{X}$ & $x$ \\
\hline LU_10 & Jasa Lainnya & $x$ & $x$ & $x$ & $x$ & $x$ & $x$ & $x$ \\
\hline LU_11 & Jasa Pariwisata & $x$ & $\mathrm{x}$ & $x$ & $x$ & $x$ & $x$ & $\mathrm{x}$ \\
\hline LU_12 & Jasa Pendidikan & $x$ & $x$ & $x$ & $x$ & $x$ & $x$ & $x$ \\
\hline LU_13 & Jasa Perdagangan & $x$ & $x$ & $x$ & $x$ & $x$ & $x$ & $x$ \\
\hline LU_14 & Jasa Perhubungan/Transportasi & $\mathrm{X}$ & $x$ & $x$ & $x$ & $x$ & $x$ & $x$ \\
\hline LU_15 & Jasa Peribadatan & $x$ & $x$ & $x$ & $x$ & $x$ & $x$ & $x$ \\
\hline LU_16 & Kebun Campuran & $\mathrm{V}$ & $\mathrm{V}$ & $\mathrm{V}$ & $\mathrm{V}$ & $\mathrm{V}$ & $\mathrm{V}$ & $\mathrm{V}$ \\
\hline LU_17 & Kolam Air Tawar & $x$ & $x$ & $x$ & $x$ & $x$ & $x$ & $x$ \\
\hline LU_18 & Kuburan/Pemakaman & $x$ & $x$ & $x$ & $x$ & $x$ & $x$ & $x$ \\
\hline LU_19 & Lapangan Olahraga & $x$ & $x$ & $x$ & $x$ & $x$ & $x$ & $x$ \\
\hline LU_20 & Padang Rumput & $\mathrm{V}$ & $\mathrm{V}$ & $\mathrm{V}$ & $\mathrm{V}$ & $\mathrm{V}$ & $\mathrm{V}$ & $\mathrm{V}$ \\
\hline LU_21 & Pergudangan & $x$ & $\mathrm{~V}$ & $x$ & V & $x$ & $x$ & $x$ \\
\hline LU_22 & Pertambangan Terbuka & $\mathrm{V}$ & $x$ & $x$ & $x$ & $x$ & $x$ & $x$ \\
\hline LU_23 & Perumahan & $x$ & $\mathrm{~V}$ & $x$ & $x$ & $\mathrm{~V}$ & $x$ & $x$ \\
\hline LU_24 & Sawah & $\mathrm{V}$ & $\mathrm{V}$ & $\mathrm{V}$ & $\mathrm{V}$ & $\mathrm{V}$ & $\mathrm{V}$ & $\mathrm{V}$ \\
\hline LU_25 & Semak & $\mathrm{V}$ & $\mathrm{V}$ & $\mathrm{V}$ & $\mathrm{V}$ & $\mathrm{V}$ & $\mathrm{V}$ & $\mathrm{V}$ \\
\hline LU_26 & Sungai & $x$ & $x$ & $x$ & $x$ & $x$ & $x$ & $x$ \\
\hline LU_27 & Taman Umum & $x$ & $x$ & $x$ & $x$ & $x$ & $x$ & $x$ \\
\hline LU_28 & Tanah Terbuka Sementara & V & $\mathrm{V}$ & V & V & V & V & V \\
\hline LU_29 & Tegalan/Ladang & $\mathrm{V}$ & $\mathrm{V}$ & $\mathrm{V}$ & $\mathrm{V}$ & $\mathrm{V}$ & $\mathrm{V}$ & $\mathrm{V}$ \\
\hline
\end{tabular}

Sebagai contoh adalah potensi perkembangan perumahan juga ditunjukkan dengan semakin terang rona cell maka semakin besar kemungkinan daerah tersebut mengalami perkembangan perumahan, sebaliknya semakin gelap rona cell maka semakin tidak berpotensi untuk mengalami perkembangan perumahan di lokasi tersebut. 


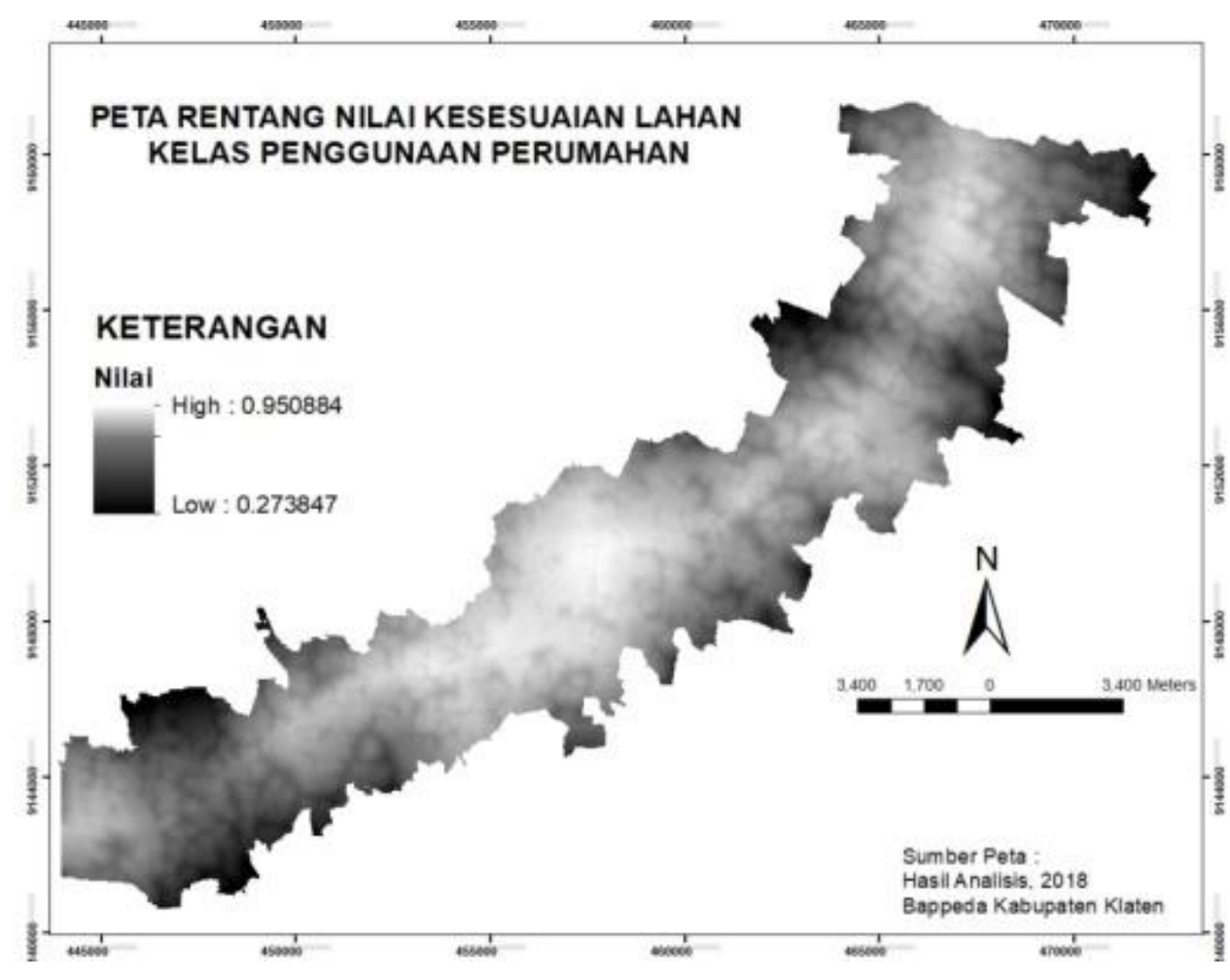

Gambar 4. Peta Potensi Transisi Perubahan Penggunaan Lahan Perumahan (Hasil Analisis,2018)

\section{Model Cellular Automata Dalam Simulasi Perubahan Penggunaan Lahan}

Input dalam analisa model cellular automata adalah hasil analisa yang sudah dilakukan sebelumnya yaitu analisa penggunaan lahan dalam time series, proyeksi perkembangan penggunaan lahan tahun 2031 dari trend perubahan lahan tahun sebelumnya, analisis peta potensi transisi dan analisis filter ketetanggan dan variabel pembatas. Tujuan dari penelitian ini adalah membuat proyeksi penggunaan tanah untuk tahun 2031 di sepanjang jalan koridor Solo-Yogyakarta di Kabupaten Klaten. Sebelum model bisa digunakan untuk memproyeksi penggunaan lahan tahun 2031 maka harus divalidasi terlebih dahulu. Dalam penelitian ini analisa validasi dilakukan pada 2 waktu tahun pemodelan, yaitu simulasi penggunaan lahan tahun 2012 dengan pengamatan tahun awal (to) adalah penggunaan lahan tahun 2007 dan simulasi penggunaan lahan tahun 2017 dengan pengamatan tahun awal (to) adalah penggunaan lahan tahun 2012.

Nilai validitas model proyeksi penggunaan lahan tahun 2017 di cari dengan membandingkan dengan penggunaan lahan tahun 2017 hasil interpretasi citra satelit dengan menggunakan analisis tabulasi silang (crosstab) untuk mencari nilai Kappa. Dari analisis crostab proyeksi tahun 2017 dengan interpretasi citra tahun 2017 diperoleh nilai Kappa sebesar 0,987 Nilai Kappa rata-rata antara model proyeksi tahun 2012 dan tahun 2017 adalah 0,986 dan artinya model proyeksi yang dibangun bias digunakan untuk memproyeksi dan meproyeksi penggunaan lahan di masa yang akan datang. 


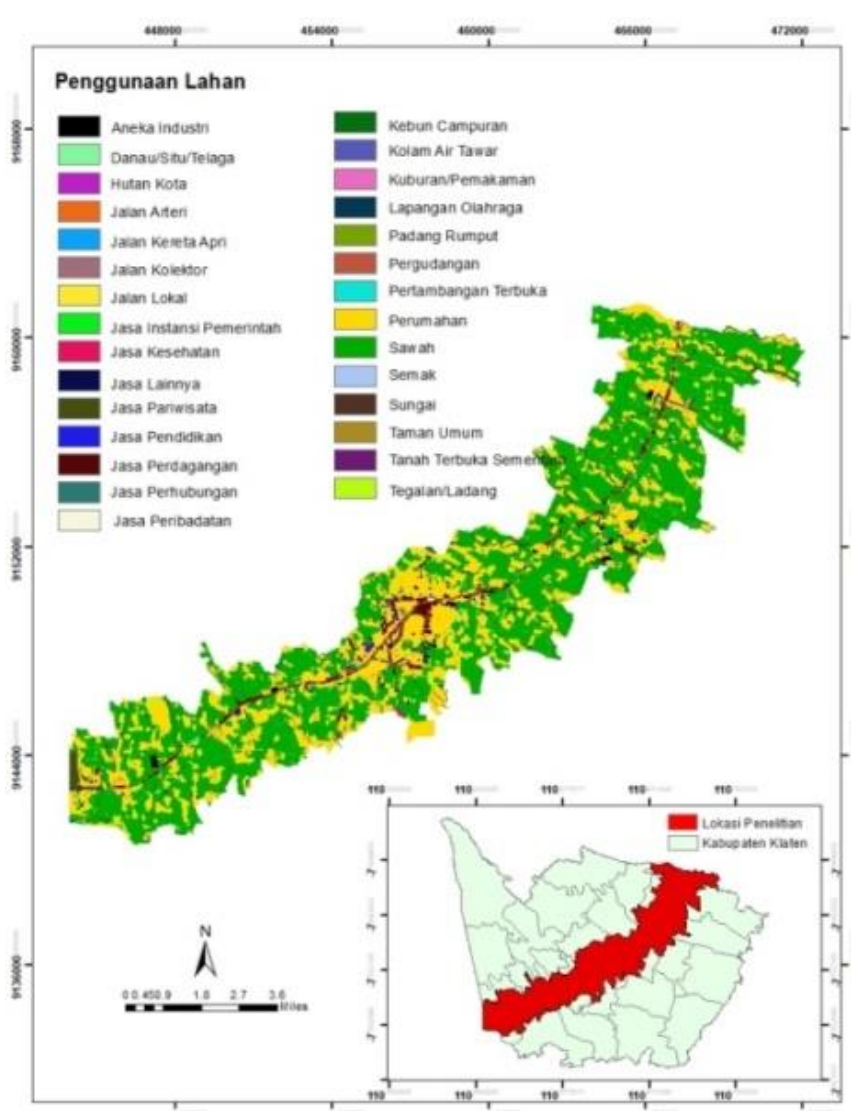

(a)

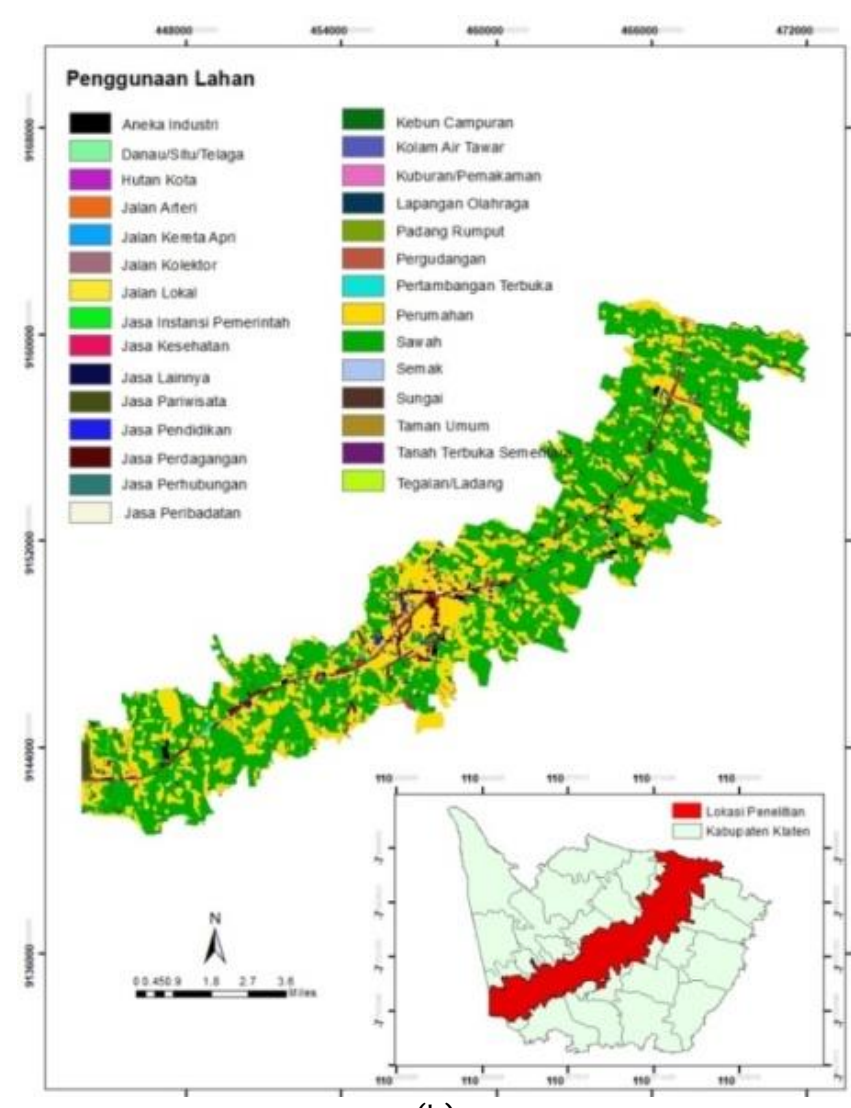

(b)

Gambar 5. Penggunaan Lahan (a) Tahun 2012 (b) Tahun 2017 Hasil Simulasi Model Cellular Automata (Hasil Analisis,2018)

5. Analisis Skenario Proyeksi Penggunaan Lahan Tahun 2031

Analisi proyeksi penggunaan lahan tahun 2031 dilakukan dalam skenario bussines as usual. Skenario bussines as usual menggambarkan kondisi dimana alokasi penggunaan lahan kurang mendapat kontrol kebijakan atau tanpa ada kebijakan khusus maupun aturan yang berlaku. Penggunaan lahan yang kurang terkontrol akan cenderung mengabaikan kesesuaian lahan karena masyarakat di berikan akses seluasluasnya untuk melakukan aktivitas dalam rangka kegiatannya termasuk melakukan konversi lahan. Kelas penggunaan tanah yang diskenariokan tidak berubah adalah Danau/Situ/Telaga, Jalan (Arteri, Kolektor dan Lokal), Jalan Kereta Api, Jasa Instansi Pemerintah, Jasa Pendidikan, Jasa Peribadatan, Jasa Kesehatan, Jasa Perhubungan, Kolam Air Tawar, Kuburan/Pemakaman, Lapangan Olahraga, Hutan Kota, Sungai dan Taman Umum.

Skenario ini menggambarkan pengaturan penggunaan lahan di area mana saja yang diperbolehkan untuk berubah dan pembatasan perubahan penggunaan lahan yang sudah diskenariokan tidak berubah dengan menggunakan data peta penggunaan lahan eksisting tahun 2017. Peta hasil proyeksi penggunaan lahan tahun 2031 disajikan dalam Gambar 6. 


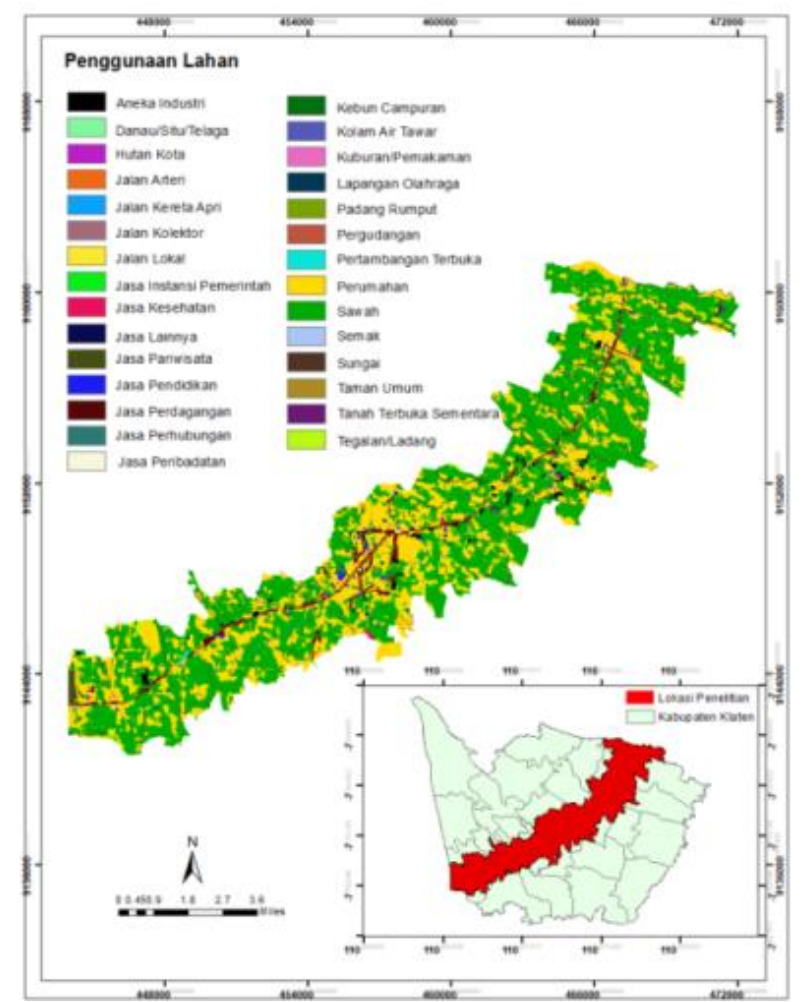

(a)

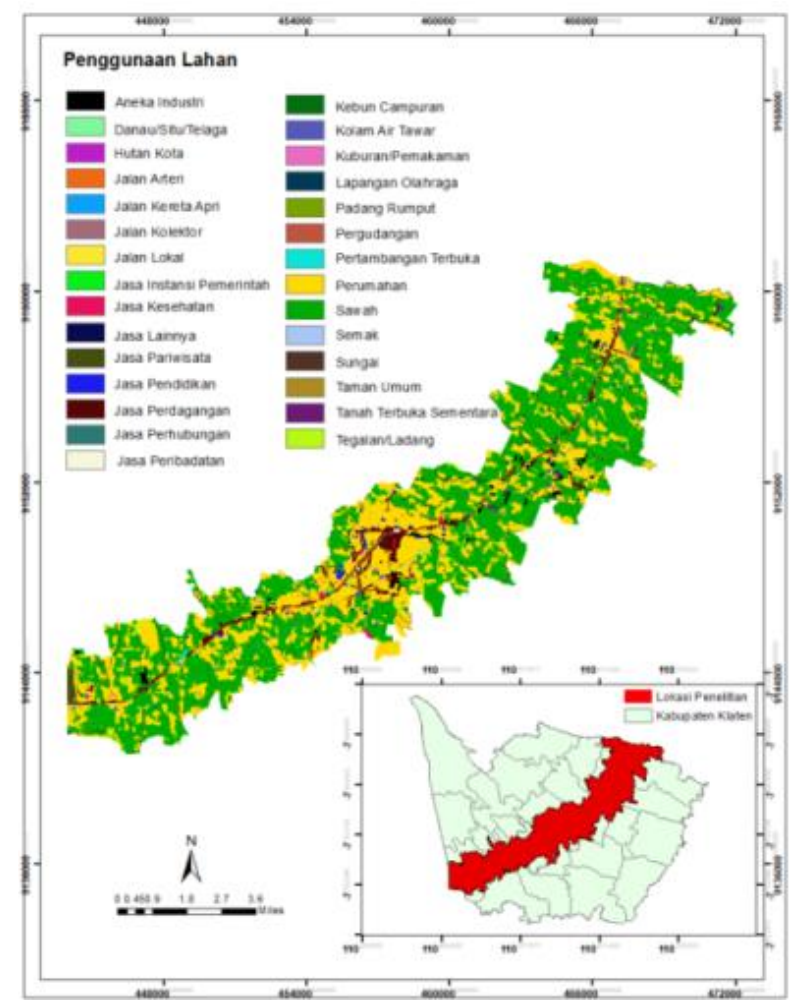

(b)

Gambar 6. Perkembangan Penggunaan Lahan (a) Tahun 2017, (b) Tahun 2031 Skenario Bussines as Usual (Hasil Analisis,2018)

Arah perkembangan Kota Klaten melihat dari hasil proyeksi penggunaan lahan tahun 2031 berdasarkan skenario bussines as usual bahwa alih fungsi lahan pertanian sawah menjadi lahan terbangun ( aneka industri, jasa perdagangan, pergudangan dan perumahan) dan lahan non terbangun yang di sekenariokan berubah (Kebun Campuran, Tanah Terbuka Sementara dan Tegalan/Ladang) masih terkonsentrasi di pusat perkotaan Kota Klaten. Kecamatan yang berpotensi mengalami pertumbuhan adalah Kecamatan Klaten Utara, Klaten Tengah, Klaten Selatan, Kalikotes, Jogonalan, Kebonarum, Ngawen, Wonosari, Ceper dan Delanggu. Sesuai dengan hasil penelitian, arah perkembangan penggunaan lahan tahun 2031 - skenario bussines as usual tergambar dalam Gambar 7.

\section{Komparasi Peta Rencana Pola Ruang dengan hasil Peta Proyeksi Penggunaan Lahan Tahun 2031}

Dalam analisis komparasi antara pola ruang RTRW kabupaten Klaten dengan peta proyeksi penggunaan lahan tahun 2031, maka harus dilakukan reklasifikasi kelas penggunaan lahan peta proyeksi tahun 2031 disesuaikan dengan kelas penggunaan lahan di rencana pola ruang RTRW. Sebelum proses overlay dilakukan maka kedua peta harus mempunyai kelas peruntukan penggunaan yang sama. Komparasi distribusi pemanfaatan lahan sesuai dengan pola ruang dengan kelas pemanfaatan lahan berupa kawasan lindung dan kawasan budidaya antara Peta Rencana Pola Ruang dengan Peta proyeksi penggunaan lahan tahun 2031 dengan pembatasan kawasan konservasi seperti tersaji dalam Gambar 4.19. Prosentasi kesesuaian kelas pemanfaatn ruang hasil analisis antara peta proyeksi tahun 2031 dengan rencana pola ruang RTRW adalah sebesar $94,42 \%$. Hasil komparasi kesesuaian pemanfaatan ruang dalam rtrw kab klaten dengan peta proyeksi penggunaan lahan tahun 2031 terlihat dalam Gambar 8. 


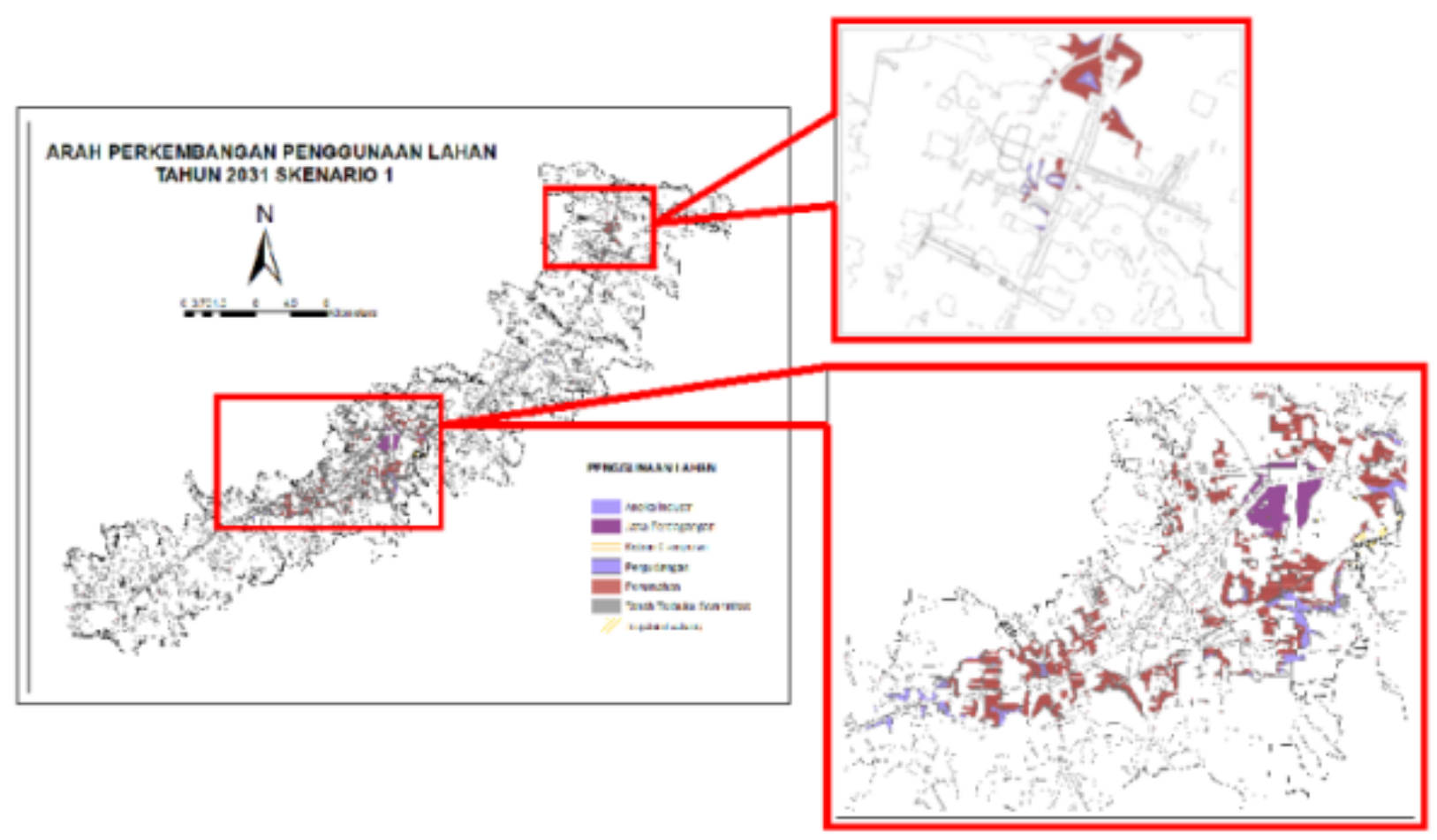

Gambar 7. Arah Perkembangan Penggunaan Lahan Tahun 2031 - Skenario Bussines As Usual (Hasil Analisis,2018)

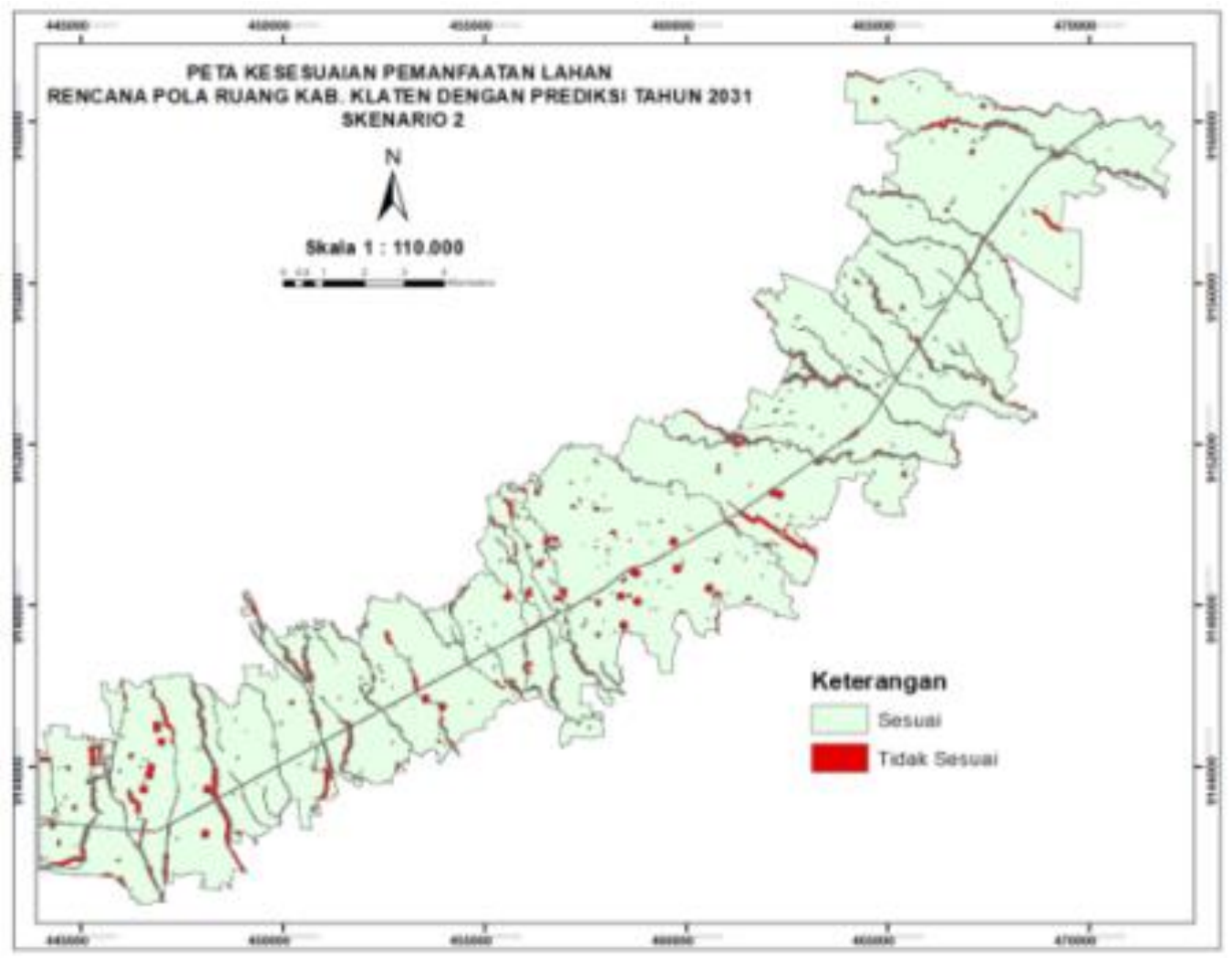

Gambar 8. Komparasi Kesesuaian Pemanfaatan Ruang Dalam RTRW Kab Klaten Dengan Peta Proyeksi Penggunaan Lahan Tahun 2031 (Hasil Analisis,2018) 


\section{KESIMPULAN}

Hasil analisis pola perubahan penggunaan lahan dari tahun 2007 sampai dengan 2017 ada 13 jenis penggunaan lahan yang mengalami perkembangan yaitu jasa pemerintahan, jasa perhubungan, taman umum, pertambangan terbuka, jasa kesehatan, jasa pendidikan, tegalan/ladang, kebun campuran, pergudangan, tanah terbuka sementara, jasa perdagangan, aneka industri dan perumahan dengan perkembangan terbesar adalah penggunaan perumahan yang mengalami kenaikan luas sebesar 217,41 $\mathrm{Ha}$, sedangkan jenis penggunaan tanah yang mengalami konversi lahan menjadi penggunaan lain adalah sawah yang mengalami penurunan luas sebesar $365.76 \mathrm{Ha}$. Berdasarkan peta proyeksi penggunaan lahan tahun 2031 bahwa arah perkembangan perubahan penggunaan lahan masih berkutat di daerah yang dekat dengan pusat kota di 10 (Sepuluh) Kecamatan yaitu Kecamatan Klaten Utara, Klaten Tengah, Klaten Selatan, Kalikotes, Jogonalan, Kebonarum, Ngawen, Wonosari, Ceper dan Delanggu. Aspek yang berpengaruh terhadap perkembangan 10 Kecamatan di masa yang akan datang adalah faktor kepadatan penduduk yang tinggi sehingga menyebabkan kebutuhan akan lahan semakin meningkat. Jarak ke pusat perkotaan juga menjadi alasan perkembangan kota Klaten di 10 Kecamatan tersebut sehingga pertumbuhan didominasi di lokasi sekitar pusat Kota Klaten dimana sarana dan prasarana fasilitas umum dan sosial tersedia secara lengkap. Hasil komparasi peta proyeksi dengan Peta Rencana Pola Ruang Wilayah Kabupaten Klaten menunjukkan hasil yang cukup sesuai dengan tingkat kesesuaian sebesar 94,42\%. Pemodelan alghoritma Cellular Automata dapat digunakan dalam menganalisa perubahan penggunaan lahan pada skala detail 1:10.000 didasarkan pada trend perubahan lahan, yaitu trend perubahan lahan dan dapat dibuat dalam beberapa skenario perubahan penggunaan lahannya.

\section{PERNYATAAN RESMI}

Pada kesempatan ini penulis mengucapkan banyak terimakasih kepada Pusbindiklatren Bappenas dan semua pihak yang telah mendukung dan membantu dalam penyelesaian penelitian ini.

\section{REFERENSI}

Ambarwulan, W., Tambunan, R. P., Nugroho, Y. A., \& Santoso, P. B. (2014). Land use planning of paddy field using geographic information system and land evaluation in West Lombok, Indonesia. Ijg, 46(1), 89-98.

Barlowe R. 1978. Land Resource economics. Third edition. Prentice. Hall inc, New Jersey.

Deep, S., \& Saklani, A. (2014). Urban sprawl modeling using cellular automata. The Egyptian Journal of Remote Sensing and Space Science, 17(2), 179-187. https://doi.org/10.1016/j.ejrs.2014.07.001

Direktur Pemetaan Tematik BPN RI. (2012). Norma, Standar, Prosedur dan Kriteria Survei Dan Pemetaan Tematik Pertanahan, Badan Pertanahan Nasional Republik Indonesia

Guan, D., Li, H., Inohae, T., Su, W., Nagaie, T., \& Hokao, K. (2011). Modeling urban land use change by the integration of cellular automaton and Markov model. Ecological Modelling, 222(20-22), 3761-3772. https://doi.org/10.1016/j.ecolmodel.2011.09.009

Helen Briassoulis, P. D. (2005). Analysis of Land Use Change: Theoretical and Modeling Approaches.

Irawan, B. (2008). Improving the Effectivity of Land Conversion Policy. Forum Penelitian Agro Ekonomi, Volume 26 No. 2, Desember 2008, 26(2), 116-131.

Lambin, E. F., Geist, H. J., \& Lepers, E. (2003). Dynamics Of Land Use And Land Cover Change In Tropical Regions. Annual Review of Environment and Resources, 28(1), 205-241. https://doi.org/10.1146/annurev.energy.28.050302.105459

T.M. Lillesand and R.W.Kiefer, 1979., Remote Sensing and Image Interpretation, John Willey and Sons, New York

Ma, C., Zhang, G. Y., Zhang, X. C., Zhao, Y. J., \& Li, H. Y. (2012). Application of Markov model in wetland change dynamics in Tianjin Coastal Area, China. Procedia Environmental Sciences, 13(2011), 252-262. https://doi.org/10.1016/j.proenv.2012.01.024

Munibah, K. (2008). Model Spasial Perubahan Penggunaan Lahan Dan Arahan Penggunaan Lahan Berwawasan 
Lingkungan (Studi Kasus DAS Cidanau, Provinsi Banten). Ipb.

Rahayu, S., Rudiarto, I., \& Pangi. (2015). Konversi Lahan Pertanian Pada Koridor Jalan Solo- Yogyakarta Di Kabupaten Klaten. Journal of Geomatics and Planning E-ISSN, 2(1), $22-29$. https://doi.org/10.14710/geoplanning.2.1.22-29

Ridwan et all. (2017). Pemodelan Perubahan Penutupan/Penggunaan Lahan Dengan Pendekatan Artificial Neural Network Dan Logistik Regression (Studi Kasus: DAS Citarum, Jawa Barat. Buletin Tanah dan Lahan 30-36

Sadewo M N. (2018). Simulasi Perubahan Penggunaan Lahan Akibat Pembangunan Kawasan Industri Berbasis Cellular Automata (Studi Kasus : Kawasan Industri Kendal). Magister Perencanaan Wilayah Dan Kota, Fakultas Teknik, Universitas Diponegoro

Septiono, D. S., \& Mussadun. (2016). Model Perubahan Penggunaan Lahan Untuk Mendukung Rencana Pengelolaan Kesatuan Pengelolaan Hutan (Studi Kasus KPH Yogyakarta ), 12(September), 277-292.

Setiady, D., \& Danoedoro, P. (2014). Prediksi Perubahan Lahan Pertanian Sawas Sebagian Kabupaten Klaten Dan Sekitarnya Menggunakan Cellular Automata Dan Data Penginderaan Jauh, Universitas Gadjah Mada

Sugandi, D., Somantri, L., \& Sugito, N. T. (2009). Sistem I Formasi Geografi ( Sig ). Hand Out Sistem Informasi Geografis (SIG).

Sulistyanto, H., \& Pulungan, R. (2014). sebuah review singkat terhadap emulasi CeLlular Automata pada mesin turing, $\mathrm{VI}(2), 142-154$.

Susilo, B. (2008). Model SIG- Binary Logistic Regression Untuk Prediksi Perubahan Penggunaan Lahan, Program Studi Teknik Geodesi dan Geomatika, Institut Teknologi Bandung.

Sutanto. (1986). Penginderaan Jauh Jilid I, Yogyakarta: Gadjah Mada University Press 